\title{
Thioredoxin Reductase 1, Cytoplasmic
}

National Cancer Institute

\section{Source}

National Cancer Institute. Thioredoxin Reductase 1, Cytoplasmic. NCI Thesaurus. Code C107618.

Thioredoxin reductase 1, cytoplasmic (649 aa, $\sim 71 \mathrm{kDa}$ ) is encoded by the human TXNRD1 gene. This protein plays a role in cellular redox reactions. 